\title{
Use of functional bandages in patients with stroke
}

\author{
Uso de bandagens funcionais em pacientes \\ com acidente vascular cerebral
}

Dreyzialle Vila Nova Mota ${ }^{[a]}$, Lícia Vasconcelos Carvalho da Silva ${ }^{[b]}$

[a] Graduate, Faculdade Asces, Caruaru, PE - Brazil, e-mail: dreyzi5@hotmail.com

[b] MSc, professor, Faculdade Asces, Caruaru, PE - Brazil, e-mail: liciavcarvalho@gmail.com

\begin{abstract}
Introduction: Functional bandages have been used in physiotherapeutic practice with the purpose of minimizing disabilities and favoring functional improvement. However, there is still a shortage of research regarding the use of these devices in patients with neurological sequelae, especially those resulting from stroke. Objective: To report the motor evolution of patients living with sequelae of stroke, who have been submitted to the use of functional bandages associated with conventional physical therapy. Materials and methods: We assessed the active range of motion, strength and degree of spasticity in the flexor and extensor muscles of the wrist and elbow joints, and functionality of the upper limb during the performance of daily activities at the first and the twentieth session of conventional physical therapy associated with the use of functional bandages. Results: There was an increase in range of motion and muscle strength of patients, and reduction in spasticity of the wrist and elbow flexor muscles. Conversely, the functionality scores remained similar before and after treatment. Conclusion: The subjects of this study showed a good evolution in the aspects studied. Thus, the use of functional bandages associated with conventional physical therapy seems to contribute to the rehabilitation of patients with stroke sequelae. Further research needs to be conducted in order to increase the scientific evidence regarding the effectiveness of functional bandages in the treatment of patients with stroke sequelae.
\end{abstract}

Keywords: Bandages. Rehabilitation. Stroke. 


\section{Resumo}

Introdução: A bandagem funcional tem sido utilizada na prática fisioterapêutica com objetivo de minimizar inabilidades e favorecer a melhora funcional. Entretanto, ainda há uma escassez de pesquisas referentes ao uso desses dispositivos em pacientes com sequelas neurológicas, especialmente aquelas decorrentes do Acidente Vascular Cerebral (AVC). Objetivo: Relatar a evolução motora de pacientes com sequelas de AVC que utilizaram bandagens funcionais associadas ao tratamento fisioterapêutico convencional. Materiais e métodos: A amplitude de movimento (ADM), força muscular, espasticidade da musculatura flexora e extensora de punho e cotovelo e funcionalidade do membro superior de cinco pacientes foram avaliadas no início do tratamento e após 20 sessões de fisioterapia convencional associada a uso de bandagens funcionais. Resultados: Houve aumento na ADM e na força muscular dos pacientes, e redução na espasticidade flexora do punho e cotovelo. Por outro lado, os escores de funcionalidade mantiveram valores semelhantes antes e após o tratamento, embora os pacientes tenham relatado maior qualidade na realização das atividades. Conclusão: Os participantes desta pesquisa tiveram boa evolução nos aspectos estudados, assim, a bandagem funcional associada à fisioterapia convencional parece ter contribuído na reabilitação desses pacientes. Outros estudos são necessários a fim de promover evidência científica sobre a eficácia das bandagens funcionais no tratamento de pacientes com sequelas de AVC.

Palavras-chave: Bandagens. Reabilitação. Acidente Vascular Cerebral.

\section{Introduction}

Functional bandages are devices used in therapeutic practice to modify the mechanics of body segments, which has been altered due to diseases or musculoskeletal disorders (1). In physical therapy, there are reports of the use of these resources in the prevention and rehabilitation of bone, muscle-tendon and joint injuries, as well as for reducing postoperative edema and muscle soreness $(2,3,4,5,6,7)$. However, there is still a paucity of research regarding the use of these devices in patients with neurological sequelae, especially those resulting from stroke.

Stroke is a clinical condition especially characterized by alterations in posture and movement resulting from changes in postural tone and may be accompanied by cognitive impairments. These changes are responsible for a range of motor and mental disabilities that impair the functional performance of patients and limit their participation in society $(8,9,10)$.

According to the literature, functional bandages provide rest to injured structures, minimizing disabilities, improving the functionality of the segments and recovering function (1). In this sense, it could be considered a useful resource for the physiotherapeutic treatment of patients with functional impairments resulting from stroke.

Considering the scarcity of scientific evidence on the use of functional bandages in the treatment of patients with stroke sequelae, the aim of this study was to describe the evolution of patients with such sequelae, who have been submitted to the use of functional bandages associated with conservative physical therapy. We hope that the data obtained in this study will indicate the existence of yet another useful resource for the treatment of patients with stroke sequelae, as well as support the conduction of further research.

\section{Materials and methods}

The study sample was composed of all patients with neuromotor sequelae of cerebrovascular accident (stroke) who were treated at the clinic of the School of Physical Therapy of the ASCES College from February to May 2011, and met the pre-established inclusion and exclusion criteria. There was a total of 7 patients. Of these, only five remained in the study.

This study aimed to measure active range of motion, strength and degree of spasticity in the flexor and extensor muscles of the wrist and elbow joints, as well as to evaluate the functionality of the upper limb in daily activities.

Inclusion criteria were: presence of limitations in functional abilities, decreased active range of motion of the wrist and elbow, and/or degree of muscle strength lower than 4 in the flexion and extension of 
the wrist and elbow of the affected limb. Exclusion criteria were: deformity in the wrist and/or elbow which prevented functional improvements; presence of other associated neurological injuries or conditions that limit joint mobility; cognitive impairment that prevented the understanding of commands and the cooperation of the individuals.

The study was approved by the Research Ethics Committee of the ASCES College - CEP / ASCES - protocol number $128 / 10$. Patients signed an informed consent form according to resolution 196/96 of the National Health Council. All volunteers were informed about the risks of the procedures and instructed not to remove the bandage on their own. If they felt any discomfort while using the bandage, they should contact the researchers at anytime and the use of the bandage would be suspended in these circumstances.

The initial plan was to conduct a clinical study with comparison group. However, because of the losses of patients and the irregular attendance of patients who composed the comparison group, we chose to conduct a case study.

Before the interventions started, patients were evaluated for active range of motion of flexion and extension of the wrist and elbow through the use of a Carci ${ }^{\circledR}$ goniometer (11). Muscle strength of the elbow and wrist extensors was measured using the Medical Research Council (MRC) scale (12). The modified Ashworth scale was used to assess the degree of spasticity $(13,14)$. Patient's functionality was assessed through the Activities of Daily Living (ADL) and Instrumental Activities of Daily Living (IADL) scales (15), adapted from the American Occupational Therapy Association (AOTA) Uniform Terminology.

Patients were followed up for 2 months (a total of 20 sessions). They were reassessed using the assessment procedures described above. The subjects this study received conservative physiotherapeutic treatment, which consisted of stretching exercises of flexor and extensor muscles of the wrist and elbow joints ( 2 sets of 30 seconds); strengthening of the same muscle groups using dumbbells ( 2 sets of 5 repetitions) (16, $17,18)$; cryo-stimulation of the extensor muscles of the wrist and elbow applied for 1 minute $(19,20)$, followed by the application of an elastic and adhesive bandage of the brand Therapy Taping directly on the skin along the area of the extensor muscles of the wrist and elbow of the affected limb.

The bandages were changed by the researcher every 3 days, according to technical recommendations
(21). Initially, they were applied on the anterior segment of the forearm and posterior segment of the arm, passing through the wrist and elbow joints, without any tension, so that the patient could adapt to the use of the device. After the first week of use, the length of the bandages was progressively shortened $3 \mathrm{~cm}$ every 4 sessions in order to increase tension on the area where it was being applied.

The results were analyzed using the Statistical Package for Social Sciences (SPSS). We used frequency distributions and statistical tests to compare the data before and after the intervention in each patient

\section{Results}

In this study, 5 patients were followed up over a period of 20 sessions. 3 patients were male and 2 female. The median age of participants was 45 years (minimum: 22, maximum: 83). 2 sessions were held weekly for ten weeks. The functional bandages used were changed every 3 days.

According to our findings, there was an increase in range of motion (ROM) for all analyzed movements, strength gains in the muscle groups assessed, and a reduction in the degree of spasticity in most patients. Functionality scores, on the other hand, showed little change after treatment, despite the qualitative improvements reported by the subjects (Table 1).

There was a reduction in the degree of spasticity in the studied muscle groups of 4 patients (Table 2).

With regard to the ROM, all patients showed gains, increasing the median of the group in flexion and extension of the wrist and in the flexion of the elbow (Figure 1).

Patient 1 had been living with cerebrovascular accident (CVA) sequelae and receiving physical therapy for two years. After the first sessions of application of the bandages, the patient reported improvement in range of motion of the wrist and fingers, and in the tactile sensitivity of the region. Throughout the interventions, she also mentioned a faster rehabilitation of the limb. The revaluation of functionality revealed a greater and better use of the affected upper limb in daily activities. The patient was able to perform household activities that she was not able to perform before the interventions because of the functional deficit that she had. 
Table 1 - Range of motion, strength, spasticity and functionality of patients at the $1^{\text {st }}$ and $20^{\text {th }}$ sessions

\begin{tabular}{|c|c|c|c|c|c|c|c|c|c|c|}
\hline & \multicolumn{2}{|c|}{ Patient 1} & \multicolumn{2}{|c|}{ Patient 2} & \multicolumn{2}{|c|}{ Patient 3} & \multicolumn{2}{|c|}{ Patient 4} & \multicolumn{2}{|c|}{ Patient 5} \\
\hline & $1^{\text {st }}$ & $20^{\text {th }}$ & $1^{\text {st }}$ & $20^{\text {th }}$ & $1^{\text {st }}$ & $20^{\text {th }}$ & $1^{\text {st }}$ & $20^{\text {th }}$ & $1^{\text {st }}$ & $20^{\text {th }}$ \\
\hline \multicolumn{11}{|l|}{ ROM (Degrees) } \\
\hline * Flexion of wrist & 60 & 90 & 43 & 70 & 0 & 0 & 30 & 40 & 13 & 90 \\
\hline * Flexion of elbow & 138 & 140 & 118 & 130 & 0 & 0 & 130 & 140 & 135 & 140 \\
\hline * Extension of wrist & 45 & 70 & 32 & 60 & 0 & 0 & 0 & 10 & 20 & 35 \\
\hline * Extension of elbow & 0 & 0 & 0 & 0 & 0 & 0 & 25 & 20 & 0 & 0 \\
\hline \multicolumn{11}{|l|}{ Strength (Degrees) } \\
\hline * Wrist flexors & 5 & 5 & 4 & 5 & 0 & 0 & 2 & 3 & 3 & 5 \\
\hline * Elbow flexors & 5 & 5 & 4 & 5 & 0 & 2 & 3 & 4 & 5 & 5 \\
\hline * Wrist extensors & 5 & 5 & 4 & 5 & 0 & 0 & 3 & 3 & 3 & 5 \\
\hline * Elbow extensors & 5 & 5 & 5 & 5 & 0 & 2 & 3 & 4 & 4 & 5 \\
\hline \multicolumn{11}{|l|}{ Spasticity (Degrees) } \\
\hline * Wrist flexors & $1+$ & 2 & 1 & 0 & 1 & 1 & 3 & 2 & 2 & 0 \\
\hline * Elbow flexors & 1 & $1+$ & 1 & 1 & $1+$ & $1+$ & 3 & 2 & 3 & 1 \\
\hline * Wrist extensors & 0 & 0 & 0 & 1 & 0 & 0 & 2 & 0 & 0 & 0 \\
\hline * Elbow extensors & 0 & $1+$ & 0 & 0 & 0 & 0 & $1+$ & $1+$ & 0 & 0 \\
\hline $\begin{array}{l}\text { Functionality } \\
\text { (maximum score: 116) }\end{array}$ & 98 & 105 & 111 & 113 & 53 & 53 & 16 & 16 & 92 & 94 \\
\hline
\end{tabular}

Source: Research data.

Table 2 - Distribution of the number of patients according to the degree of spasticity at the beginning and at the end of the treatment

\begin{tabular}{|c|c|c|c|c|c|c|c|c|}
\hline \multirow[b]{2}{*}{ Degrees } & \multicolumn{2}{|c|}{ Flexion of wrist } & \multicolumn{2}{|c|}{ Extension of wrist } & \multicolumn{2}{|c|}{ Flexion of elbow } & \multicolumn{2}{|c|}{ Extension } \\
\hline & $1^{\text {st }}$ session & $20^{\text {th }}$ session & $1^{\text {st }}$ session & $20^{\text {th }}$ session & $1^{\text {st }}$ session & $20^{\text {th }}$ session & $1^{\text {st }}$ session & $20^{\text {th }}$ session \\
\hline 0 & & 02 & 04 & 04 & & & 04 & 03 \\
\hline 1 & 02 & 01 & & 01 & 02 & 02 & & \\
\hline $1+$ & 01 & & & & 01 & 02 & 01 & 02 \\
\hline 2 & 01 & 02 & 01 & & & 01 & & \\
\hline 3 & 01 & & & & 02 & & & \\
\hline 4 & & & & & & & & \\
\hline
\end{tabular}

Source: Research data. 
ROM of flexion of the wrist

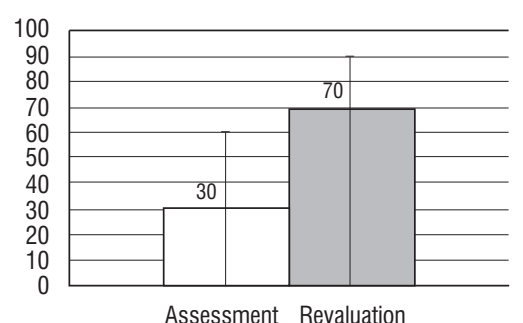

ROM of extension of the wrist

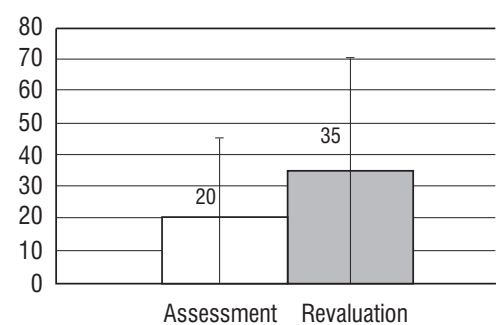

ROM of flexion of the elbow

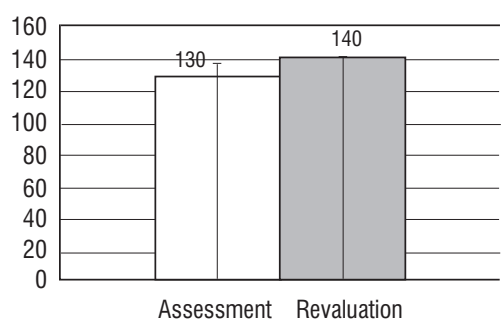

Figure 1 - Medium, maximum and minimum values of range of motion of flexion of the wrist and elbow, and extension of the wrist of patients at $1^{\text {st }}$ session (evaluation) and $20^{\text {th }}$ session (revaluation)

Source: Research data.

Patient 2 had been living with stroke sequelae for two years and six months and undergoing physical therapy for two years. The patient was fully independent in activities of daily living (ADL) using the healthy upper limb, but had difficulties in performing fine activities with the paretic limb. Throughout the sessions, the patient reported improvements in positioning and greater feeling of lightness in the affected limb. The revaluation of functionality showed that the patient was able to carry light objects and feed himself more easily using the affected limb after the intervetions.

Patient 3 had had a second stroke episode one month prior to participating in the study, and the first episode 6 years before that. He had no sequelae from the first stroke and had been undergoing physical therapy for three weeks. His affected upper limb was paralyzed and he was totally dependent in daily activities. During the intervention, the patient exhibited hyperemic skin and small cutaneous lesions near the area where the bandages were placed. These symptoms disappeared after a few days, not interfering in the conduction of the study. At the fifth session of application, the patient showed muscle contraction without gravity (degree 2) for the elbow flexors, but the strength degree did not evolved until the end of the applications. The patient reported decreased pain in the affected limb.

Patient 4 had been living with stroke sequelae for 9 years and had begun with physical therapy soon after discharge. He was dependent in most daily activities, performing some of them with assistance, like washing himself, drying himself after a shower or brushing his teeth. The only activity independently performed by the patient before starting the therapy used in this study was feeding himself. Late in the course of the study, the patient started using his affected limb more often.

Patient 5 had been living with stroke sequelae for 3 years and undergoing physical therapy for 2 years. She had been using wrist orthosis for 1 year and reported feeling discomfort and pain in the limb during the use of the orthosis. In the course of the sessions, the patient decreased the frequency of use of the orthosis, despite having been instructed to continue using it during the study. She performed most daily activities alone, and ony needed help to get dressed, do her nails and perform housework. Throughout the sessions, the patient reported pain relief in the affected limb, better movement quality during daily life tasks performance, and greater ease in the extension of the fingers of the paretic upper limb. The revaluation of functionality showed that the patient started to perform housework independently.

\section{Discussion}

The aim of using functional bandages is to normalize the biomechanics of the segments and contribute to the regulation of the muscle tone by facilitating synergistic activity and joint alignment (4). Moreover, they should help reduce irritation of the neural tissue, 
directly or indirectly inhibiting the pain associated with movement. Thus, there is an optimization of movement coordination, facilitating the reestablishment of proprioception (22).

Even though all these benefits could be found in the literature, there are also studies that report that the functional bandage had no significant effect in patients with neurological sequelae.

A clinical trial aiming to measure the effect of bandages in reducing spasticity of the ankle plantar flexors in gait speed and in step length in 20 hemiplegic patients undergoing botulinum toxin injection found no clear advantage in the associated application of functional bandages (23). However, it is important to stress that botulinum toxin acts by blocking the release of acetylcholine at the neuromuscular junction, leading to muscle paralysis with prolonged effect for a few months (24). This would explain the ineffectiveness of bandages when associated with botulinum toxin in the study.

In this study, 4 patients showed improvement in spasticity in all muscle groups. In a case study on the influence of orthostatism on trunk control and spasticity in paraplegic patients, the authors state that spasticity may be influenced by factors such as anxiety, muscle fatigue, temperature and depression (25). This could justify the increased spasticity observed in 1 patient, since she reported that she had been taking on household activities with more intensity due to health problems in the family and was feeling tired on the day of the revaluation.

In a clinical trial, researchers evaluated the effects of functional bandage on gross motor function and level of functional independence in thirty children with cerebral palsy. The children were divided into two groups: an experimental group and a control group, and the trial lasted twelve weeks. The authors found no direct effects of the use of such bandages on the gross motor function and functional independence of these children. They suggested that the use of functional bandages may be beneficial in some clinical situations when combined with conventional physical therapy (26).

Conversely, in a study conducted with 15 children aged 4 to 16 years who had muscle weakness or change in muscle tone due to acquired lesions as stroke (CVA), Traumatic Brain Injury (TBI) and brain tumor, the authors reported improvements in functional motor skills of the upper extremity after the use of bandages (27).
In this study, results showed that patients began to use the affected limb more frequently. During the use of functional bandages associated with conservative treatment we could observe an improvement in the quality of movements performed by the patients, which facilitates the performance of daily activities. Improved functionality may be related to the proprioceptive biofeedback achieved through the positioning offered by the bandage. When the joint is moved outside of this alignment, the patient immediately perceives a tension and is encouraged to correct the movement. With repetition, these patterns become components of motor learning, and the external stimulus to correct joint alignment becomes no longer necessary (22).

In a literature review, some methods of rehabilitation of the upper limb in adult patients with post-stroke hemiplegia have been discussed, such as Functional Electrical Stimulation (FES), Bobath and elastic bandage. The authors concluded that the use of bandages together with a rehabilitation program is important in reducing pain, inflammation, muscle weakness and maintaing alignment of the upper limb in these patients (28). This agrees with the findings of this study, in which all patients showed gains in muscle strength and decreased pain in the affected limb.

The activation of weakened muscles seems to result from an indirect mechanism. The tegumentary stimulation made possible by this resource would trigger cutaneous mechanoreceptors, which would then take that information to the central nervous system in order to elicit a motor response (29). In addtion to this sensory stimulation, there would be an increase in blood and lymph circulation (30). Psychological effects are also reported by users, such as a sensation of comfort and independence (1).

A case report assessed the effect of bandages on range of motion (ROM) and spasticity in the ankle of a 4-year-old child with spastic diparetic cerebral palsy, walking difficulties and congenital talipes equinovarus. The bandage was used only in the right lower limb for comparison. The authors observed a $30^{\circ}$ gain in dorsiflexion of the right ankle (when compared with the left ankle) and spasticity decreased in all muscles studied (31). These results are similar to those found in this study, in which patients showed improvements throughout the sessions in ROM in the muscle groups evaluated. This could be justified by the activation of muscles, regulation of tonus and correction of joints, which are favored by the use of functional bandages, 
allowing a more functional axis of movement and an increase in ROM (4).

\section{Conclusion}

The use of elastic bandages together with the application of conventional kinesiotherapy proved to be a useful approach in the physiotherapeutic treatment of five patients who participated in this study. Our findings indicated a gain in range of motion and in strength, reduced spasticity in the affected upper limb and greater independence in performing activities of daily living, with an improvement in the quality of movements performed. There were also reports of reduced pain in the upper limb of patients, a symptom which was not measured in this study.

We conclude that the volunteers who participated in this study showed a good evolution in the aspects studied. This suggests that the use of functional bandages associated with conventional physical therapy could be effective in the rehabilitation of stroke patients. However, further research needs to be conducted with larger samples in order to increase the scientific evidence regarding the benefits of this device in the treatment of neurological sequelae.

\section{References}

1. Cerveny GC. Estudo eletromiográfico dos músculos bíceps femoral (Cabeça longa), semitendíneo e semimembranáceo na contração isométrica voluntária máxima em 30, 60 e 90 graus de flexão da perna, com e sem o uso de bandagem funcional (dissertação). Piracicaba: Universidade Estadual de Campinas; 2001.

2. Tebmann UJ, Schmidt J. Neue Aspekte in der Nachbehandlung distaler Radiusfrakturen. Aktuelle Traumatol. 2006;36:11(3)3-17.

3. Airaksinen O, Kolari PJ, Miettinen H. Elastic bandages and intermittent pneumatic compression for treatment of acute ankle sprains. Arch Phys Med Rehabil. 1990;71(6):380-3.

4. Barreto RA, Azevedo RCS, Jorge FS, Ribeiro Jr. SMS. Efeito da bandagem neuromuscular em atletas de futebol durante a simulação entorse de tornozelo por inversão: uma análise eletromiográfica. Perspectivas Online. 2010;4(13):181-93.
5. Meana RM, José LE, Ignácio GR, Xavier AJ. Biomecanica do tornozelo com a bandagem funcional preventiva. Arch Med Deporte. 2004;2:99-108.

6. Whitelaw GP, DeMuth KA, Demos HA, Schepsis A, Jacques E. The use of the Cryo/Cuff versus ice and elastic wrap in the postoperative care of knee arthroscopy patients. Am J Knee Surg. 1995;8(1):28-30.

7. Paoloni M, Bernetti A, Fratocchi G, Mangone M, Parrinello L, Del-Pilar-Cooper M, et al. Kinesio Taping applied to lumbar muscles influences clinical and electromyographic characteristics in chronic low back pain patients. Eur J Phys Rehabil Med. 2011; 47(2):237-44.

8. Corrêa FI, Soares F, Andrade DV, Gondo RM, Peres, JA, Fernandes AO. Atividade muscular durante a marcha após acidente vascular encefálico. Arq Neuropsiquiatr. 2005;63(3B):847-51.

9. Neves PP, Fontes SV, Fukujima MM, Matas SLA, Prado GF. Profissionais da saúde, que assistem pacientes com Acidente Vascular Cerebral, necessitam de informação especializada? Rev Neurociênc. 2004;12(4):173-81.

10. Perlini NMOG, Faro ACM. Cuidar de pessoa incapacitada por acidente vascular cerebral no domicílio: o fazer do cuidador familiar. Rev Esc Enferm USP. 2005; 39(2):154-63.

11. Silva SS, Fonseca EATS, Souza HRR, Mendes EC, Carvalho RW. Análise do comportamento cinemático da marcha de um indivíduo submetido a artroplastia total de quadril. Fisioter Bras. 2005;6(3):230-3.

12. Parreira SLS, Resende MBD, Peduto MDC, Marie SKN, Carvalho MS, Reed UC. Quantificação da força muscular e habilidades motoras em pacientes com distrofia muscular de Duchenne em corticoterapia. Arq NeuroPsiquiatr. 2007;65(2):245-50.

13. Cardoso E, Rodrigues B, Lucena R, Oliveira IR, Pedreira G, Melo A. Toxina botulínica proporciona melhora funcional em pacientes com espasticidade secundária a acidente vascular cerebral?. Arq Neuro-Psiquiatr. 2007;65(3):592-5.

14. Minutoli VP, Delfino M, Freitas STT, Lima MO, Tortoza C, Santos CA. Efeito do movimento passivo contínuo isocinético na hemiplegia espástica. Acta Fisiatr. 2007; 14(3):142-8. 
15. Rocha TT. Roteiro para observação das AVD e AIVD. 2010 (cited 2010 Jun 13). Available from: http:// www.ciape.org.br/matdidatico/telma/avaliacoes_ funcionais.doc

16. Horn AI, Fontes SV, Carvalho SMR, Silvado RAB, Barbosa PMK, Durigan Jr A, et al. Cinesioterapia previne ombro doloroso em pacientes hemiplégicos/paréticos na fase subaguda do acidente vascular encefálico. Arq Neuro-Psiquiatr. 2003;61(3B):768-71.

17. Marino Jr. NW, Ferreira LS, Pastre CM, Valério NI, Lamari NM, Marino LHC. Intervenção fisioterapêutica na síndrome do ombro doloroso em portadores de hemiplegia. Arq Cienc Saude. 2005;12(4):220-2.

18. Souza SRS, Oliveira CA, Mizuta NA, Santos MHMR, Moreira AP, Feitosa AL. Reabilitação funcional para membros superiores pos-acidente vascular encefálico. Fisioter Bras. 2003;4(3):195-9.

19. Shappo EW, Biscaro F, Spredemann R. Efeito da crioterapia na extensão passiva de punho de pacientes com traumatismo raquimedular cervical: estudo de caso. Fisioter Bras. 2003;4:449-53.

20. Correia ACS, Silva JDS, Silva LVC, Oliveira DA, Cabral ED. Crioterapia e Cinesioterapia no membro superior espástico no acidente vascular cerebral. Fisioter Mov. 2010;23(4):555-63

21. Almeida A, Gonçalves P, Silva MA, Machado L. 0 efeito da aplicação de ligaduras funcionais no padrão de marcha e controlo postural em crianças hemiplégicas espásticas por paralisia cerebral. Rev Port Cien Desp. 2003;7(1):48-58.

22. Santos GH, Sampaio-Jorge F, Vizella RM, Silva J. A influência da bandagem funcional na atividade eletromiográfica de músculos do ombro durante arremesso de handball. Perspectivas Online. 2008;5(2):64-72.

23. Saygi EK, Aydoseli KC, Kablan N, Ofluoglu D. The role of kinesiotaping combined with botulinum toxin to reduce plantar flexors spasticity after stroke. Top Stroke Rehabil. 2010;17(4):318-22.

24. Osaki MH, Belfort Jr. R. Qualidade de vida e custos diretos em pacientes com blefaroespasmo essencial e espasmo hemifacial, tratados com toxina botulínica-A. Arq Bras Oftalmol. 2004;67(1):43-9.
25. Leite, JV, Rael S, Castro W, Vicentini A. Influência do ortostatismo no controle de tronco e na espasticidade de pacientes paraplégicos. Intellectus. 2008;4:363-70.

26. Simşek TT, Türkücüoğlu B, Çokal N, Ustünbaş G, Simşek IE. The effects of Kinesio ${ }^{\circledR}$ taping on sitting posture, functional independence and gross motor function in children with cerebral palsy. Disabil Rehabil. 2011;33(21-22):2058-63.

27. Yasukawa A, Patel P, Sisung C. Pilot study: investigating the effects of Kinesio Taping in an acute pediatric rehabilitation setting. Am J Occup Ther. 2006;60(1):104-10.

28. Jaraczewska E, Long C. Kinesio taping in stroke: improving functional use of the upper extremity in hemiplegia. Top Stroke Rehabil. 2006;13(3):31-42.

29. Marcolino J, Mendes L, Vieira TS, Morini N. Aplicação da bandagem terapêutica Therapy Taping ${ }^{\circledR}$ em um caso de linfedema submandibular após radioterapia. Anais do 17. Congresso Brasileiro de Fisioterapia e 1. Congresso Ibero-Americano de Fonoaudiologia; 21-24 de outubro 2009, Salvador.

30. Ribeiro MO, Raha RO, Kokanj AS, Bittar DP. O O uso da bandagem elástica Kinesio no controle da sialorréia em crianças com paralisia cerebral. Acta Fisiatr. 2009;16(4):168-72.

31. Greve P, Perez VJ, Yoshizumi LM, Morini N, Faria TCC, Bérzin F, et al. Effect of the bandage kinesio taping ${ }^{\circledR}$ in spasticity in cerebral palsy of diparetic - case report. In: Proceedings of the 14th World Physical Therapy; 2003 June 7-12; Barcelona.

Received: 11/13/2013 Recebido: 13/11/2013

Approved: 06/03/2014 Aprovado: 03/06/2014 